\title{
Identification, Characterization, and Expression Analysis of Spondin-Like and Fasciclin-Like Genes in Neopyropia yezoensis, A Marine Red Alga
}

\author{
Toshiki Uji *D, Shinnosuke Ueda and Hiroyuki Mizuta
}

Citation: Uji, T.; Ueda, S.; Mizuta, H. Identification, Characterization, and Expression Analysis of Spondin-Like and Fasciclin-Like Genes in

Neopyropia yezoensis, A Marine Red Alga. Phycology 2022, 2, 45-59. https://doi.org/10.3390/ phycology2010003

Academic Editor: Peer Schenk

Received: 15 October 2021

Accepted: 5 January 2022

Published: 6 January 2022

Publisher's Note: MDPI stays neutral with regard to jurisdictional claims in published maps and institutional affiliations.

Copyright: (C) 2022 by the authors. Licensee MDPI, Basel, Switzerland. This article is an open access article distributed under the terms and conditions of the Creative Commons Attribution (CC BY) license (https:// creativecommons.org/licenses/by/ $4.0 /)$.

\author{
Division of Marine Life Science, Faculty of Fisheries Sciences, Hokkaido University, Hakodate 041-8611, Japan; \\ enzerudazou1@eis.hokudai.ac.jp (S.U.); mizuta@fish.hokudai.ac.jp (H.M.) \\ * Correspondence: t-uji@fish.hokudai.ac.jp; Tel./Fax: +81-138-40-8864
}

\begin{abstract}
Extracellular matrix (ECM) proteins play crucial roles in the regulation of cell proliferation and differentiation. We identified homologous genes encoding ECM proteins that are known to associate with integrins in animal cells in red macroalga Neopyropia yezoensis. Four genes encoding spondin domain-containing proteins (NySPLs) and eight genes encoding fasciclin domain-containing proteins (NyFALs) from $N$. yezoensis were selected for bioinformatics and expression analysis in order to obtain insights into the roles of ECM proteins for the life cycle. NySPLs had eight $\beta$-strands with two contiguous $\alpha$-helices, which were similar to those of the F-spondin domain of animals. NyFALs had conserved $\mathrm{H} 1$ and $\mathrm{H} 2$ motifs and a $\mathrm{YH}$ motif between the $\mathrm{H} 1$ and $\mathrm{H} 2$ regions. Quantitative reverse transcription polymerase chain reaction showed that NySPL1-3 and NyFAL8 transcripts were highly accumulated in mature gametophytes that formed the spermatia. Furthermore, expressions of all NySPLs were upregulated in response to the ethylene precursor 1-aminocylopropane-1-carboxylic acid that induces gametogenesis. NyFAL1, 4 were highly expressed in sporophytes, whereas NyFAL2, $3,5,6$, and 7 were overexpressed in gametophytes, especially at the vegetative stage. These findings facilitate future research on ECM architecture in the unique life cycles of red macroalgae.
\end{abstract}

Keywords: extracellular matrix proteins; fasciclin; Neopyropia; red algae; spondin

\section{Introduction}

The extracellular matrix (ECM) not only provides structural support for organs and tissues in the form of basement membranes but also regulates cell-cell communication and signaling [1,2]. ECMs from macroalgae, which are commonly referred to as the cell wall, are complex assemblages of cellulose, various hemicelluloses, and unique sulfated polysaccharides (ex. agars and carrageenans) [3]. With regard to the research on ECMs, many reports focus on the ECM polysaccharides, because they are main components of cell wall structures in addition to useful materials for gel-forming agents, cosmetics, biofuels, nutraceuticals, and pharmaceuticals [4].

ECM proteins are among the most important ECM components that regulate cell proliferation and differentiation by binding to multiple interacting partners, such as other ECM proteins and signal receptors [2,5]. In animal cells, integrins, which are a superfamily of cell adhesion receptors, trigger various signal transduction events that modulate cell behavior, such as adhesion, proliferation, polarity, differentiation, and gene expression, by binding to ECM ligands [6,7].

The marine red algae Bangiophyceae, such as Neopyropia, Porphyra, and Pyropia, is one of the most important marine aquaculture crops harvested for human food. Bangiophyceae has a heteromorphic life cycle, with alterations between its blade gametophyte and filamentous sporophyte [8,9] (Figure 1). A previous study showed the gametophyte and sporophyte of Bangiophyceae differ markedly in the composition of the ECM polysaccharides [10]. In addition, the reproductive regions of Bangiophyceae gametophyte differ 
from vegetative regions in the sugar composition of ECMs [11-13]. Thus, ECM remodeling appears to occur during the life cycle of Bangiophyceae species. However, in contrast to ECM polysaccharides, our knowledge of the role of ECM proteins during the unique life cycle remains limited in spite of the availability of Bangiophyceae genome data sets [14-16].

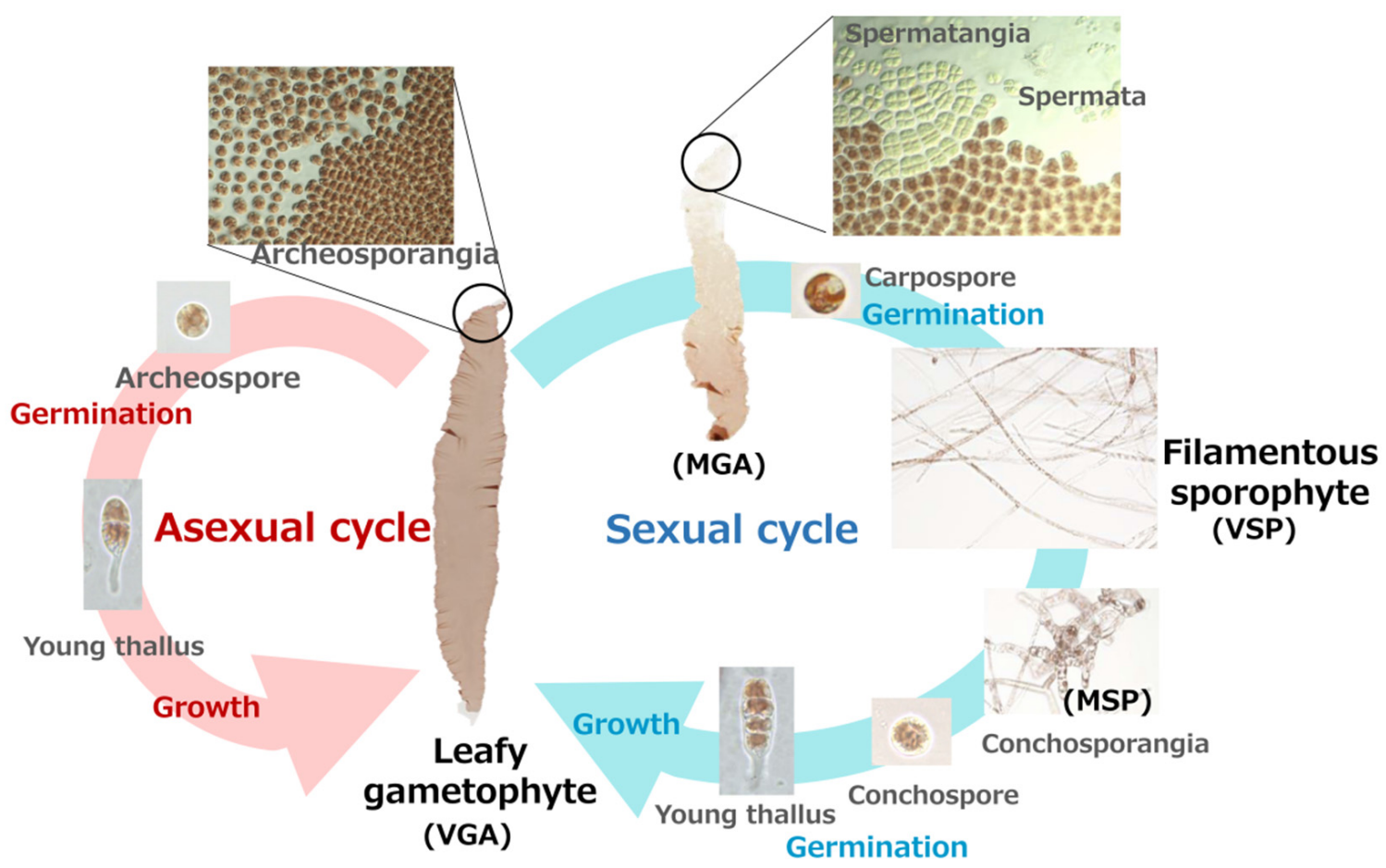

Figure 1. Life cycle of the marine red alga Neopyropia yezoensis. The mature gametophytes of Bangiophyceae form male (spermatia) and female gametes (carpogonia) during sexual reproduction. After fertilization occurs, released zygotes (called carpospores) grow into filamentous sporophytes (called Conchocelis). Mature sporophytes subsequently produce conchospores that are released from the conchosporangia and settle on the substratum, where they germinate to form new gametophytes. In addition to the sexual life cycle, some species, such as Neopyropia yezoensis, have an asexual life cycle in which asexual spores termed as archeospores (or monospores) are produced, which subsequently reproduce gametophytic thallus. VGA: vegetative gametophytes formed vegetative cells only; MGA: mature gametophytes formed sexual cells; VSP: vegetative sporophytes formed vegetative cells only; MSP: mature sporophytes formed conchosporangia.

Bangiophyceae does not appear to possess integrin adhesion and signaling systems similar to animals. However, upon exploring the genomic data of N. yezoensis, we found homologs of ECM proteins that interact with integrins in animal cells, such as F-spondin and fasciclin. The spondin family, including F-spondin and Mindin, are the molecules that are attached to the ECM [17]. The F-spondin molecule consists of approximately 800 amino acids that contains domains of homologous to reelin, FS domain, and multiple TSR repeats (five in invertebrate and six in vertebrate) [18], while Mindin contains an FS domain and one TSR domain [19]. Structural studies suggested that the FS domain, which exhibits a homology structure similar to that of the $\mathrm{C} 2$ domain functions as membrane-targeting modules through $\mathrm{Ca}^{2+}$-dependent [20]. The F-spondin family, which was identified in animal species, including rats [21], Xenopus [22], Drosophila [19], and zebrafish [18], influences the patterning of the nervous system by promoting adhesion and outgrowth of commissural axon [23]. In contrast, members of the fasciclin I family of proteins (FAS1), which are ancient extracellular proteins, are found in many vertebrates, invertebrates, plants, and microorganisms [24]. FAS1 also participates in cell adhesion and communication for diverse biological processes, such as axon guidance, morphogenesis, and cell proliferation [25,26]. 
Mammalian FAS1 are thought to bind to different types of integrins that mediate mechanical contact between the cytoskeleton and the ECM as well as transduce intracellular signals using numerous associated proteins [24,27]. In higher plants, FAS1 domain proteins, named FLAs, were identified as a group of hydroxyproline-rich glycoproteins (HRGPs) called AGPs [28]. FLAs have a plethora of biological roles, such as the maintenance of cell wall architecture, regulation of male gametophyte and seed development, and enhancement of root growth and shoot regeneration [29-34].

Fossil records (ca.1000 Mya) of Bangiomorpha, which closely resemble the extant Bangiophyceae, provide the oldest evidence of sexually reproducing eukaryotes, since it is possible to observe both spore and gamete formation $[35,36]$. The findings imply that Bangiophyceae species possess a primitive ECM remodeling mechanism for progression of the life cycle. In the present study, we identified and characterized candidate ECM genes including four spondin-like (NySPLs) and eight fasciclin-like (NyFALs) genes in N. yezoensis that is harvested to produce nori in Japan toward our understanding of the role of ECM for ancestral developmental and reproductive processes.

\section{Materials and Methods}

\subsection{Algal Materials and Treatments}

Leafy gametophytes and filamentous sporophytes of the N. yezoensis strain TU-1 [37] were cultured at $15{ }^{\circ} \mathrm{C}$ in sterile vitamin-free Provasoli's enriched seawater (PES; [38]) under a $10 \mathrm{~h}$ light $/ 14 \mathrm{~h}$ dark photoperiod provided using cool-white, fluorescent lamps at a light intensity of $40 \mu \mathrm{mol}$ photons $\mathrm{m}^{-2} \mathrm{~s}^{-1}$, as described previously [39].

Vegetative gametophytes that microscopically formed only vegetative cells and mature gametophytes that produced clusters of spermatangia were frozen with liquid nitrogen and stored at $-80{ }^{\circ} \mathrm{C}$ until the RNA was extracted for quantitative reverse transcription polymerase chain reaction (qRT-PCR). Similarly, vegetative sporophytes that formed only vegetative cells and mature sporophytes that produced conchosporangia were also frozen and stored at $-80^{\circ} \mathrm{C}$. Observation of vegetative and reproductive cells was performed by a Leica DM 5000 B microscope.

In our previous study, gametophytes treated with Hsp90-inhibiting drugs, such as geldanamycin (GA) and radicicol (RAD), induced the formation of archeosporangia [40]. Thus, to induce an asexual life cycle, vegetative gametophytes were cultured at $15^{\circ} \mathrm{C}$ under a $10 \mathrm{~h}$ light/14 h dark photoperiod in a PES medium containing $5 \mu \mathrm{M}$ RAD (Cayman Chemical Company) that was prepared by dissolving RAD in dimethyl sulfoxide (DMSO) for 7 days. Simultaneously, the control experiment was conducted using a DMSO-containing culture at concentrations corresponding to the same volume of the reagent. Alternatively, to induce sexual life cycle, vegetative gametophytes grown to a blade length of 20-30 mm were used for transcriptional analyses under 1-aminocylopropane-1-carboxylic acid (ACC) treatments. Then, for ACC treatments, cultured algae were treated with PES medium containing $50 \mu \mathrm{M}$ ACC (Tokyo Chemical Industry, Tokyo, Japan). The gametophytes that induced asexual and sexual reproduction by the reagents were also frozen and stored at $-80{ }^{\circ} \mathrm{C}$.

\subsection{Transcriptional Analysis of NySPL and NyFAL Genes}

RNA extraction and qRT-PCR were performed as described previously [41]. Total RNA from gametophytes and sporophytes (Fresh weight: 0.05-0.1 g) was separately extracted using the RNeasy Plant Mini Kit (Qiagen, Hilden, Germany) in liquid nitrogen with a mortar and pestle, following the manufacturer's instructions. Then, extracted RNA was purified using the TURBO DNA-free kit (Invitrogen/Life Technologies, Carlsbad, CA, USA) to obtain DNA-free RNA samples. Afterward, first-strand cDNA was synthesized from $0.5 \mu \mathrm{g}$ total RNA using PrimeScript II 1st strand cDNA Synthesis Kit (TaKaRa Bio, Shiga, Japan). For subsequent qRT-PCR, obtained cDNA was diluted 10 -fold and $1.0 \mu \mathrm{L}$ of the diluted cDNA was used as a template in a 20-microlitre reaction volume. qRT-PCR was performed using the KOD SYBR ${ }^{\circledR}$ qPCR Mix kit (TOYOBO, Osaka, Japan), following the manufacturer's instructions. Real-time PCR was then conducted using a LightCycler ${ }^{\circledR} 480$ 
System (Roche Diagnostics, Basel, Switzerland) under the following conditions: $30 \mathrm{~s}$ at $95^{\circ} \mathrm{C}$, followed by 40 cycles of $5 \mathrm{~s}$ at $95^{\circ} \mathrm{C}$ and $31 \mathrm{~s}$ at $55^{\circ} \mathrm{C}$. Expression levels for each NySPL and NyFAL gene were calculated using the $2^{-\triangle \triangle \mathrm{Ct}}$ method [42], and the levels were normalized to the level of the transcription elongation factor 1 (PyElf1) gene [43]. Finally, relative expression levels of the examined genes were calculated as a ratio of the mRNA level to the transcription level at the vegetative gametophyte stage at 0 day after ACC treatment. qRT-PCR was conducted in triplicate. Table S1 lists the primers used in this study.

\subsection{Bioinformatic Analysis}

After the functional annotation of draft N. yezoensis genome sequence [14] was analyzed using Blast2GO software (https: / / www.blast2go.com/) (accessed on 8 June 2021) with an E value cutoff of $1 \times 10^{-4}$ [44], four genes encoding spondin domain-containing proteins (NySPLs) and eight genes encoding fasciclin domain-containing proteins (NyFALs) were identified by key word search on the annotated genome. Based on these sequences, complete open reading frames were retrieved from $N$. yezoensis genome sequence data (ASM982973v1). The protein sequences from NySPLs and NyFALs were blasted against NCBI database using BLASTp with the default parameter. Then, their isoelectric points (pIs) and molecular weights (Mws) were calculated using ExPASy (http: / / web.expasy.org/cgi-bin/compute_pi/) (accessed on 5 August 2021) [45]. Conserved domains were confirmed using the "ScanProsite" feature under ExPASy (http:/ / tw.expasy. org/tools/scanprosite/) (accessed on 5 August 2021), and the PROMALS3D multiple protein sequences alignment program (http:/ / prodata.swmed.edu/promals3d/promals3 d.php) (accessed on 21 August 2021) [46] was used to align the deduced amino acid sequences. PSORT II (https:/ / psort.hgc.jp/form2.html) (accessed on 25 August 2021) [47] was used to predict the algae's subcellular localization, and the NetNGlyc 1.0 Server (http: / / www.cbs.dtu.dk/services/NetNGlyc/) (accessed on 25 August 2021) [48] was used to predict $\mathrm{N}$-glycosylation sites using artificial neural networks that can examine Asn-Xaa-Ser/Thr sequences.

\section{Results}

\subsection{Characterization of Spondin Domain-Containing Proteins}

The F-spondin family of proteins includes both F-spondin and M-spondin/Mindin that share similarities in their F-spondin (FS) domains and thrombospondin repeat (TSR) domains $[18,19]$. In this study, four genes encoding FS domain-containing proteins were identified from the $N$. yezoensis genome sequence and were named NySPL1-4 (spondinlike proteins) (Figure S1). Details of NySPL proteins, including protein length, molecular weight, pI, and predicted subcellular localizations are listed in Table 1 . The lengths of the NySPL proteins ranged from 223 to 232 amino acid residues, whereas predicted pI values ranged from 5.13 to 10.37 . NySPLs had 45-49\% similarity of the FS domain of human F-spondin. Furthermore, BLAST analysis showed that the protein sequences of NySPLs exhibited a 45-72\% identity with FS domain-containing proteins from Porphyra umbilicalis. All four NySPLs lacked a TSR domain.

Table 1. Characteristics of NySPL proteins identified in Neopyropia yezoensis genome.

\begin{tabular}{cccccc}
\hline Name & Contig ID & Size (aa) & pI & Mw (KDa) & $\begin{array}{c}\text { Predicted } \\
\text { Location }\end{array}$ \\
\hline NySPL1 & contig_17719_g4350 & 228 & 5.78 & 24.64 & extracellular \\
NySPL2 & contig_23899_g5890 & 223 & 10.37 & 24.18 & extracellular \\
NySPL3 & contig_29619_g7276 & 232 & 9.69 & 24.46 & extracellular \\
NySPL4 & contig_33564_g8106 & 224 & 5.13 & 22.55 & extracellular \\
\hline aa-amino acid; pl-isoelectric point; Mw-Molecular weight.
\end{tabular}

aa-amino acid; pI-isoelectric point; Mw-Molecular weight. 
Secondary structure analysis revealed that all four NySPLs had eight $\beta$-strands with two contiguous $\alpha$-helices, which were similar to those of the FS domain from animals (Figure 2A). Multiple sequence alignment showed that all NySPLs had two highly conserved sequences, i.e., "PSPDW" and "DAGTD", in the FS domain. These conserved sequences comprised three aspartic acid residues, which functioned as a solvent-accessible $\mathrm{Ca}^{2+}$-binding site [20]. The results also showed that the $\mathrm{N}$-linked glycosylation site in the FS domain from humans was conserved in NySPL1, 3. Likewise, a putative N-glycosylation site was detected within other NySPL proteins. However, the integrin-binding LEV triplet found in the FS domain of human, mouse, and rat mindins [49] was not conserved in NySPLs.

\subsection{Characterization of Fasciclin Domain-Containing Proteins}

Although the overall sequence conservation among FAS1 domains is low, two conserved sequence motifs called $\mathrm{H} 1$ and $\mathrm{H} 2$ exist [50]. Another conserved central [Phe/Tyr]His (YH) motif, with approximately 10 amino acids in each conserved region has also been identified [50]. Prokaryotic representatives typically contain a single FAS1 domain, whereas many eukaryotic FAS1 family members contain two or more FAS1 domains in tandem [24]. In this study, eight genes encoding FAS1 domain-containing proteins were identified from the $N$. yezoensis genome sequence and were named NyFAL1-8 (fasciclin-like protein) (Figure S1). Details of the identified NyFAL proteins are listed in Table 2.

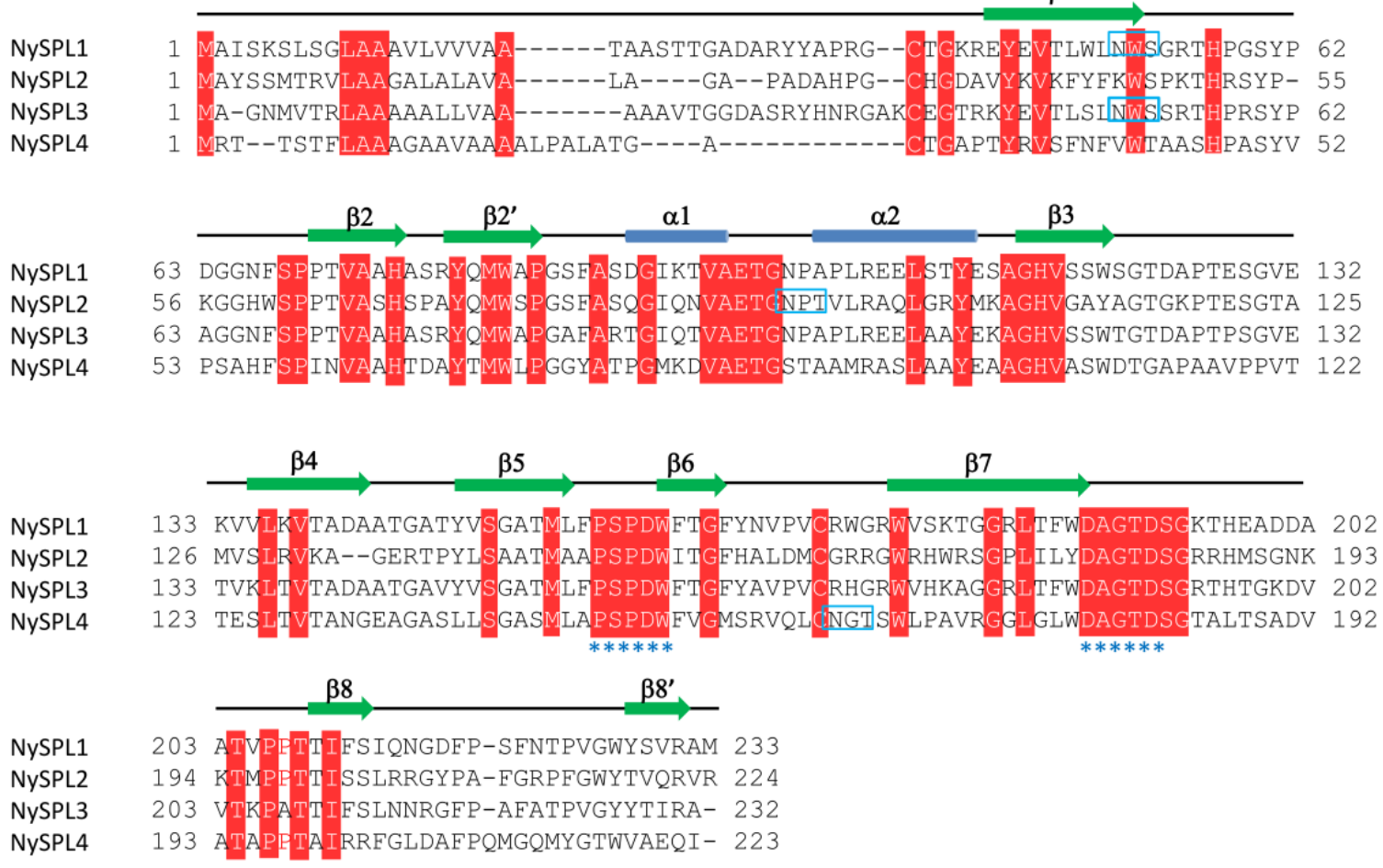

(A)

Figure 2. Cont. 


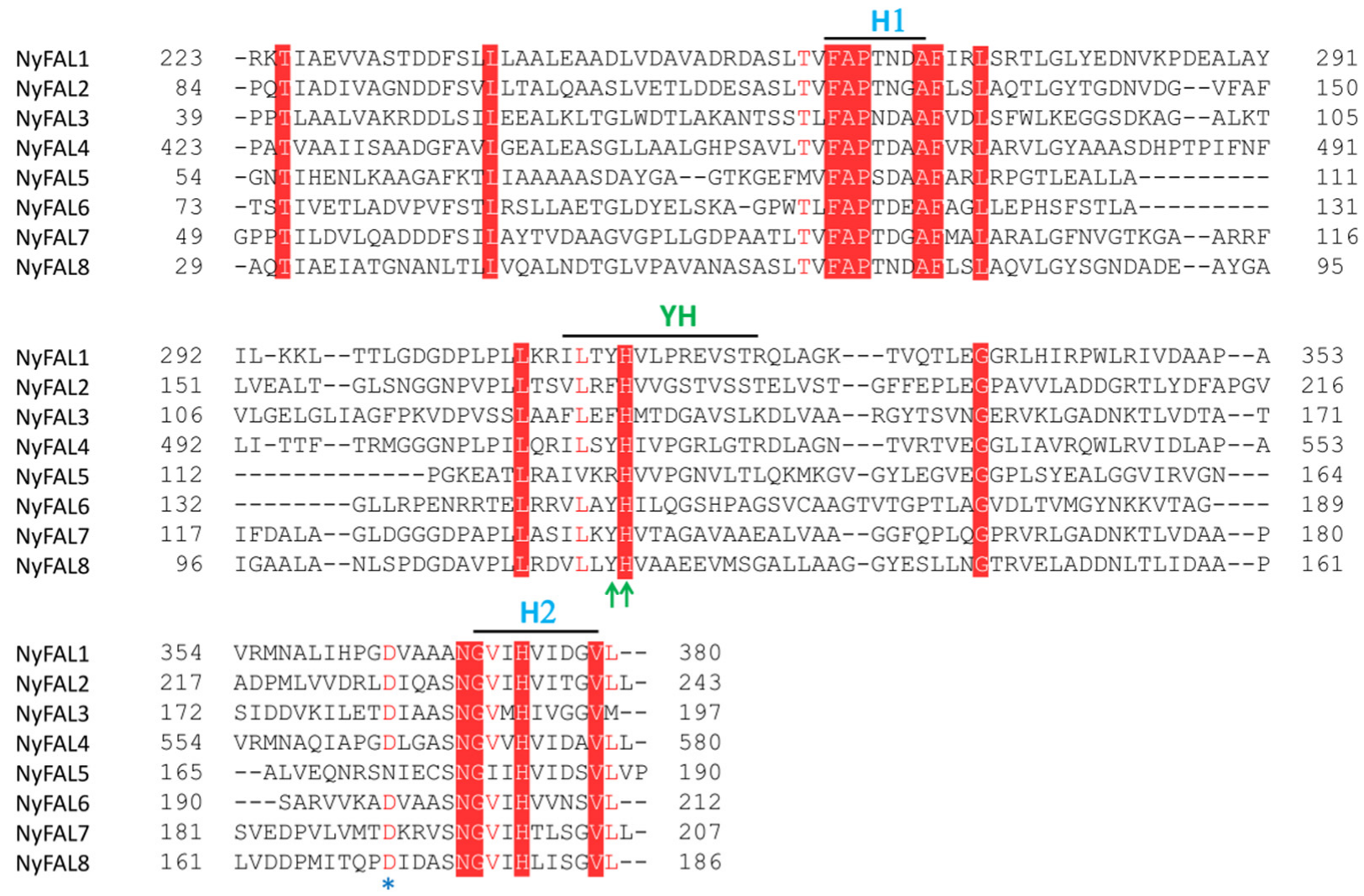

(B)

Figure 2. Sequence characteristics of NySPLs and NyFALs. (A) Sequence alignment of spondin-like proteins (NySPLs) identified in Neopyropia yezoensis. The PROMALS3D multiple protein sequences alignment program was used to align the deduced amino acid sequences of four NySPLs. Secondary structure elements are denoted using blue cylinders ( $\alpha$-helices) and green arrows ( $\beta$-strands). Identical residues are highlighted in red. Two highly conserved sequences "PSPDW" and "DAGTD" in the FS domain are marked using asterisks. A putative $\mathrm{N}$-glycosylation site is indicated using a box. Numbers represent amino acid positions from the first methionine residue. (B) Sequence alignment of fasciclin domain-containing proteins (NyFALs) identified in Neopyropia yezoensis. The PROMALS3D multiple protein sequences alignment program was used to align deduced amino acid sequences of fasciclin domains in eight NyFALs. Characteristics of fasciclin $\mathrm{H} 1$ and $\mathrm{H} 2$ conserved domains are indicated below the alignment. The conserved residue Asp, proposed to be involved in cell adhesion, is marked using an asterisk, and $\mathrm{YH}$ motifs are indicated using green arrows.

Table 2. Characteristics of NyFAL proteins identified in Neopyropia yezoensis genome.

\begin{tabular}{|c|c|c|c|c|c|}
\hline Name & Contig ID & Size (aa) & pI & Mw (KDa) & $\begin{array}{l}\text { Predicted } \\
\text { Location }\end{array}$ \\
\hline NyFAL1 & contig_12094_g2891 & 414 & 8.59 & 43.5 & extracellular \\
\hline NyFAL2 & contig_12570_g3010 & 1124 & 4.06 & 114.15 & membrane \\
\hline NyFAL3 & contig_15884_g3808 & 204 & 5.37 & 20.89 & cytoplasmic \\
\hline NyFAL4 & contig_23059_g5692 & 611 & 11.25 & 61.98 & membrane \\
\hline NyFAL5 & contig_29738_g7294 & 336 & 8.98 & 34.6 & mitochondria \\
\hline NyFAL6 & contig_33001_g7988 & 266 & 8.55 & 27.48 & $\begin{array}{l}\text { endoplasmic } \\
\text { reticulum }\end{array}$ \\
\hline NyFAL7 & contig_38449_g8982 & 442 & 5.01 & 44.87 & mitochondria \\
\hline NyFAL8 & contig_39761_g9180 & 406 & 4.54 & 40.53 & extracellular \\
\hline
\end{tabular}

aa-amino acid; pI-isoelectric point; Mw-Molecular weight. 
The length of the identified NyFAL proteins ranged from 204 to 1124 amino acids, and predicted pI values ranged from 4.06 to 11.25 . NyFAL3, 5, 6, and 8 contained a single fasciclin domain, whereas NyFAL1, 4, and 7 had two fasciclin domains. In contrast, NyFAL2 comprised five fasciclin domains. BLAST analysis showed that the protein sequences of NyFAS exhibited 42-89\% identities with fasciclin domain-containing proteins from $P$. umbilicalis. Multiple sequence alignment results showed that the FAS1 domain in NyFALs had conserved $\mathrm{H} 1$ and $\mathrm{H} 2$ motifs and the $\mathrm{YH}$ motif between the $\mathrm{H} 1$ and $\mathrm{H} 2$ regions (Figure 2B). In addition, seven NyFALs (except for NyFAL5) had conserved aspartic acid residues near the $\mathrm{H} 2$ region of the FAS1 domain, similar to those found in human, mice, Drosophila, and sea urchins, which are proposed to be essential for cell adhesion activity [51]. It has previously been reported that FAS1 domain-containing proteins from higher plants belong to arabinogalactan proteins (AGPs), named fasciclin-like AGPs (FLAs) [50]. Classical AGPs contain at least 50\% PAST (P, proline; A, alanine; S, serine; $\mathrm{T}$, threonine), but FLAs contain less than 35\% PAST [52,53]. Among the NyFALs examined in this study, NyFAL4 had a pro-rich region located between two FAS1 domains and contained $64.5 \%$ PAST (Pro: 47.6\%, Ala: $9.2 \%$, Ser: 3.3\%, Thr: $4.2 \%$ ).

\subsection{Expression Profiles of NySPL Genes at Different Developmental Stages}

mRNA transcripts of NySPL genes were examined at different developmental stages (Figure 3). Expression analysis showed that the transcripts of NySPL1-3 genes were highly accumulated in mature gametophytes that formed the spermatia and NySPL4 had a relatively low expression in sporophytes.

Our previous research revealed that the exogenous application of ACC, a precursor of the phytohormone ethylene, induced gametogenesis in N. yezoensis [39,54,55]. Therefore, the expression patterns of NySPL genes were examined in response to ACC (Figure 4). The expression of NySPL1, 3, and 4 remarkably increased by 35.6 to 91.0-fold after 1 day of ACC treatment, and this increase immediately decreased 7 days after treatment. In contrast, the expression of NySPL2 increased after 1 day and gradually decreased later. In contrast to sexual reproduction, no remarkable increase in the expression of all NySPL genes was observed in gametophytes that formed archeosporangia (Figure S2).

\subsection{Expression Profiles of NyFAL Genes at Different Developmental Stages}

The amount of NyFAL1 and NyFAL4 mRNA was large in sporophytes (272.0-fold to 446.7-fold at vegetative sporophytes, respectively). In contrast, $N y F A L 2,3,5,6$, and 7 were highly expressed in gametophytes, especially at the vegetative stage (except for NyFAL7) (Figure 5). Results showed that NyFAL8 was highly expressed in mature gametophytes. The exogenous application of ACC increased NyFAL8 expression levels by 2.0-fold after 3 days (data not shown). Similarly to the results obtained with NySPLs, none of the NyFALs remarkable increased transcripts in gametophytes that formed the archeosporangia (Figure S3). 

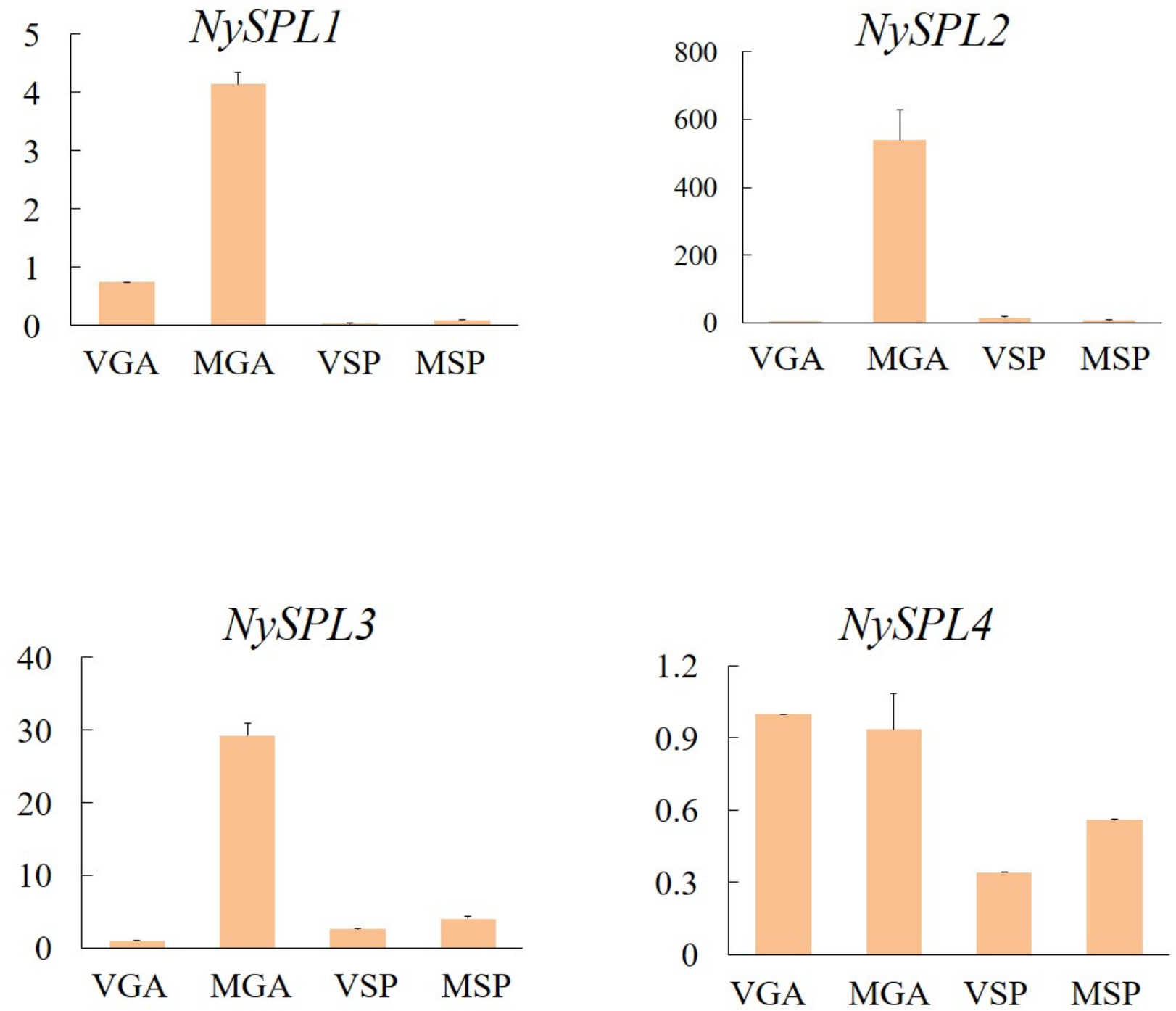

Figure 3. Relative expression levels of NySPLs genes in Neopyropia yezoensis at different developmental stages. RNA samples were prepared from vegetative gametophytes, which formed vegetative cells only (VGA). Mature gametophytes formed sexual cells (MGA). In contrast, vegetative sporophytes formed vegetative cells only (VSP), whereas mature sporophytes formed conchosporangia (MSP). Expression levels were assessed using the NyElf1 gene for normalization. Data are presented as means \pm standard deviations $(n=3)$. 

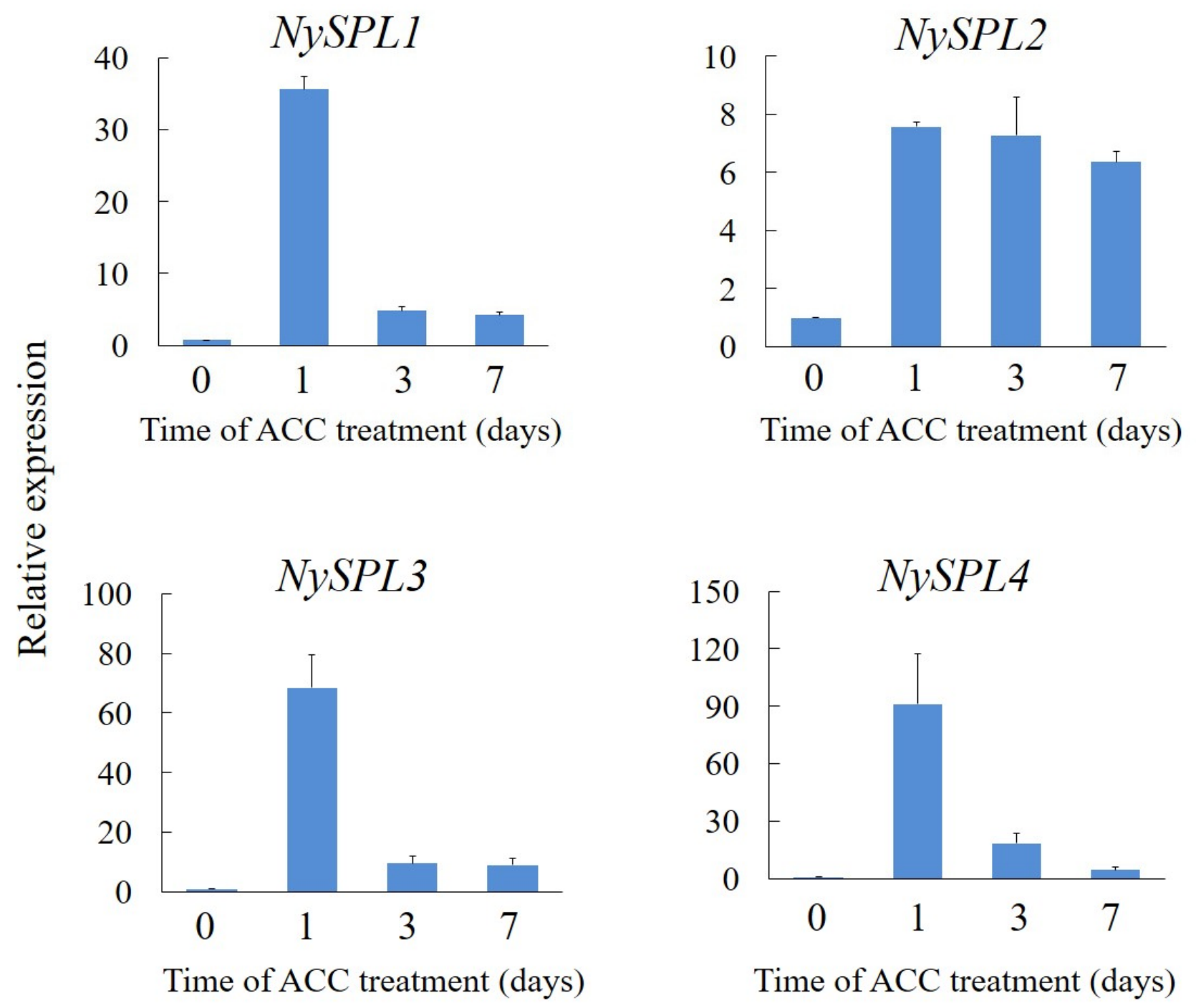

Figure 4. Relative expression levels of NySPLs genes in Neopyropia yezoensis during sexual reproduction in response to 1-aminocylopropane-1-carboxylic acid (ACC). RNA samples were prepared from gametophytes treated with 1-aminocylopropane-1-carboxylic acid (ACC) for 1, 3, or 7 days. Expression levels were assessed using NyElf1 for normalization. Results were then presented as relative expression and compared with that in non-treated gametophytes ( 0 day). Data are presented as means \pm standard deviations $(n=3)$. 

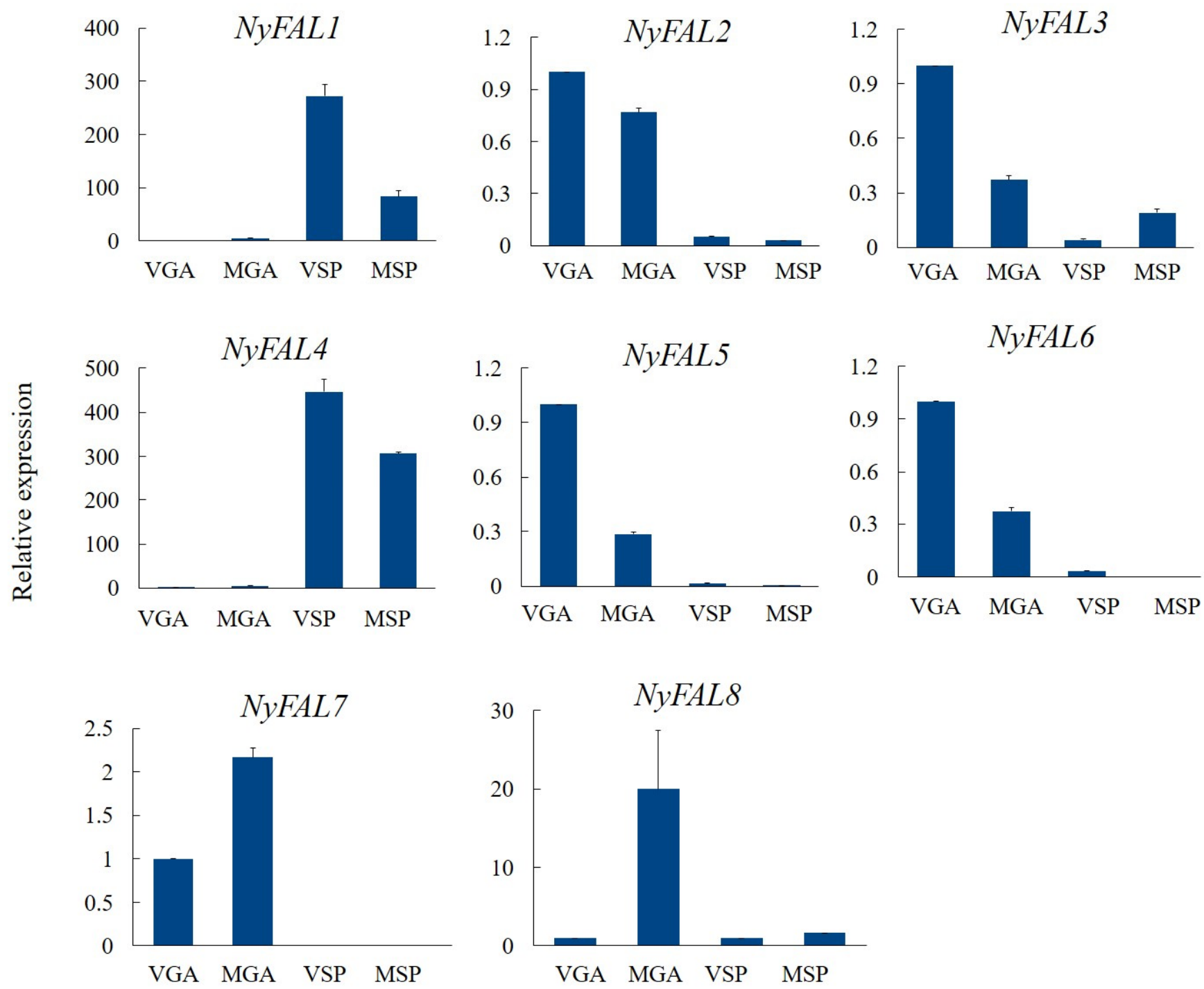

Figure 5. Relative expression levels of NyFALs genes in Neopyropia yezoensis at different developmental stages. RNA samples were prepared from vegetative gametophytes, which formed vegetative cells only (VGA). Mature gametophytes formed sexual cells (MGA), whereas vegetative sporophytes formed vegetative cells only (VSP). In contrast, mature sporophytes formed conchosporangia (MSP). Expression levels were assessed using the NyElf1 gene for normalization. Data are presented as means \pm standard deviations $(n=3)$.

\section{Discussion}

ECM serves as not only a physical scaffold to cells but also a dynamic structure remodeled by physiological cell conditions. An increasing body of evidence indicates that ECM proteins are involved in the regulation of cell proliferation, migration, adhesion, and differentiation through cell-cell communication and signal transduction in animals and land plants [2,56]. Previous studies showed the different compositions of ECM polysaccharides between gametophyte and sporophyte/vegetative and reproductive stages in Bangiophyceae [10-13]. However, little is known about the role of ECM proteins associated with generation-specific (gametophyte and sporophyte) and reproduction-specific ECM architecture in Bangiophyceae species. In this study, we identified homologous genes encoding ECM proteins such as F-spondin and fasciclin that are known to interact with integrins. The accumulation of knowledge of NySPLs and NyFALs are valuable for understanding roles of ECM systems without integrin family as ECM receptors. 
Structural studies have revealed that the FS domain from animals exhibits a homology structure similar to that of the $\mathrm{C} 2$ domain, which is a membrane-targeting domain involved in signal transduction or membrane trafficking in a $\mathrm{Ca}^{2+}$-dependent manner $[20,49,57]$. The FS domain of F-spondin from humans was found to be a solvent-accessible $\mathrm{Ca}^{2+}$ binding site, formed from D325, D354, and D358. Therefore, these results suggest that the FS domain is responsible for part of the $\mathrm{Ca}^{2+}$-dependent membrane targeting of $\mathrm{F}$ spondin [20]. NySPLs have similar secondary structures to that of FS domains from animals as well as three conserved aspartic acid residues that serve as $\mathrm{Ca}^{2+}$-binding sites (Figure 2). In addition, qRT-PCR analysis showed that NySPLs transcripts increased in gametophytes treated with ACC that is an inducer of the gametogenesis. Thus, NySPLs may function as intercellular adhesion and signal transduction for sexual reproduction in a $\mathrm{Ca}^{2+}$-dependent manner.

The spondin family from animals, including F-spondin and Mindin, consists of FS domain and TSR domain $[17,58]$. On the other hand, the results of our study revealed that all four NySPLs consisted of about 200 amino acids with FS domains, but they lacked a TSR domain that promotes cell adhesion in various cell types [21]. In addition to NySPLs, we found FS domain-containing proteins without TSR in other organisms, such as corals. Although research on F-spondins and mindins that have a TSR domain as well as an FS domain has been advanced, functional analysis of spondins lacking a TSR domain, including NySPLs, is important for understanding the evolution of cell adhesion molecules.

In higher plants, FAS1 domain proteins, which are categorized as a group of HRGPs, have a plethora of biological roles including the maintenance of cell wall architecture and regulation of development [29-34]. Furthermore, a two-FAS1 domain-containing protein obtained from the colonial green alga Volvox carteri, called Algal-CAM, influences the formation of intercellular contacts during early embryogenesis [59]. A study showed that Algal-CAM, in addition to these two FAS1 domains, contained Ser-Pro rich region, with Pro residues that were likely hydroxylated [59]. These findings indicated that the FAS1 domain from green algae and higher plants was closely related to HRGPs, which are important plant cell wall components [28]. Among NyFALs examined in this study, NyFAL4 contains a Pro-rich region between two FAS1 domains, and their transcripts were highly accumulated in the sporophyte stage (Figure 5). The sporophyte of Bangiophyceae has a different cell wall composition (main cell wall polymer is cellulose), morphology (filamentous), and growth behavior (tip growth) compared to the gametophyte $[10,60]$. Thus, the preferential expression of NyFAL4 in the sporophyte suggests that NyFAL4 may play an important role in cell wall architecture for sporophyte-specific growth and development. In contrast to NyFAL4, NyFAL2, 3, 5, 6, and 7 were highly expressed in gametophytes, which implicates their involvement in development at the gametophyte stage, for example, maintenance of blade shape.

Previous reports showed that FAS1 domain protein from Arabidopsis, AtFla4, localized to the developing mucilage pocket of seed coat epidermal cells, and AtFla10 and AtFla17 were identified in a proteome of mature mucilage [61]. Among NyFALs, NyFAL8 transcripts were highly accumulated in mature gametophytes that formed sexual cells (Figure 5). During sexual reproduction in Bangiophyceae species, the mucilage is synthesized in sexual cells, which is responsible for attachment to male and female gametes and the protection of the spores until cell wall deposition $[12,13,62]$. These findings imply that NyFAL8 may be involved in mature mucilage during N. yezoensis reproduction.

$\mathrm{N}$-linked protein glycosylation modulates ECM protein conformation and activity, thereby affecting cell-ECM interactions [63]. In this study, putative N-glycosylation sites were detected within all four NySPL and four NyFAL proteins. Glycosylation reactions are catalyzed by glycosyltransferases, which add sugar chains to various complex carbohydrates [64]. Our previous study showed that the transcripts of the GT14 gene encoding a homolog of $\mathrm{N}$-acetylglucosaminyltransferase, which can transfer $\mathrm{N}$-acetylglucosamine (GlcNAc) to an acceptor substrate, were upregulated in N. yezoensis gametophytes that induced sexual reproduction in response to treatment with ACC [65]. In the present study, 
we also found that expression levels of NySPLs increased after ACC treatment (Figure 4). Thus, N-glycan structures of NySPLs during sexual reproduction should be investigated in the future to elucidate the role of N-linked protein glycosylation in ECM protein activity.

\section{Conclusions}

N. yezoensis is proposed to be absent in the integrin system, but possesses integrinrelated ECM components, such as spondin domain-containing and fasciclin domaincontaining proteins. Bioinformatics and expressions analysis imply that NySPLs may play an important role in intercellular adhesion and signal transduction for sexual reproduction in a $\mathrm{Ca}^{2+}$-dependent manner. NyFALs had conserved aspartic acid residues near the $\mathrm{H} 2$ region of the FAS1 domain, which are proposed to be essential for cell adhesion activity in animals. Among NyFALs, NyFAL4 had a pro-rich region located between two FAS1 domains and exhibited sporophyte-preferential expression, suggesting that NyFAL4 may involve in cell wall architecture for filamentous morphogenesis and tip growth at the sporophyte stage. In addition to the functional analysis of NySPLs and NyFLAs, the identification of membrane receptors or other ECM proteins that interact with NySPLs and NyFLAs can help us better understand not only the role of ECM remodeling in Bangiophyceae life cycle but also its ancient cell adhesion mechanisms.

Supplementary Materials: The following supporting information can be downloaded at the following website: https:/ / www.mdpi.com/article/10.3390/phycology2010003/s1, Figure S1: Schematic representations of the conserved domains of NySPLs and NyFALs. Domains were determined by searching NySPL and NyFAL sequences in ScanProsite. FS; F-spondin domain, FAS1; Fasciclin 1 domain. The position of the putative N-glycosylation site is indicated using a triangle. Numbers correspond to amino acid positions from the first methionine residue; Figure S2: Relative expression levels of NySPLs genes in Neopyropia yezoensis during asexual reproduction. RNA samples were prepared from gametophytes treated with Hsp90-inhibiting drug, radicicol (RAD), or dimethyl sulfoxide (DMSO, control) for 7 days. Expression levels were assessed using NyElf1 for normalization. Results were then presented as relative expression and compared with that in non-treated gametophytes (0 day). Data are presented as means \pm standard deviations $(n=3)$; Figure S3: Relative expression levels of NyFALs genes in Neopyropia yezoensis during asexual reproduction. RNA samples were prepared from gametophytes treated with Hsp90-inhibiting drug, radicicol (RAD), or dimethyl sulfoxide (DMSO, control) for 7 days. Expression levels were assessed using NyElf1 for normalization. Results were then presented as relative expression and compared with that in non-treated gametophytes (0 day). Data are presented as means \pm standard deviations $(n=3)$; Table S1: The list of primers used for gene expression analysis by quantitative Real-Time PCR.

Author Contributions: T.U. was responsible for the design of the experiments and interpretation of data. T.U. and S.U. performed the experiments. T.U. and H.M. wrote the manuscript. All authors have read and agreed to the published version of the manuscript.

Funding: This study was supported by a grant-in-aid for Young Scientists (19K15907 to TU) from the Japan Society for the Promotion of Science.

Institutional Review Board Statement: Not applicable.

Informed Consent Statement: Not applicable.

Data Availability Statement: Data are contained within the article.

Acknowledgments: We are grateful to Katsutoshi Arai and Takafumi Fujimoto (Hokkaido University, Japan) for kindly providing the LightCycler 480 system.

Conflicts of Interest: The authors declare no conflict of interest. 


\section{References}

1. Hynes, R.O. The Extracellular Matrix: Not Just Pretty Fibrils. Science 2009, 326, 1216-1219. [CrossRef] [PubMed]

2. Kim, S.H.; Turnbull, J.; Guimond, S. Extracellular matrix and cell signalling: The dynamic cooperation of integrin, proteoglycan and growth factor receptor. J. Endocrinol. 2011, 209, 139-151. [CrossRef]

3. Kloareg, B.; Badis, Y.; Cock, J.M.; Michel, G. Role and Evolution of the Extracellular Matrix in the Acquisition of Complex Multicellularity in Eukaryotes: A Macroalgal Perspective. Genes 2021, 12, 1059. [CrossRef]

4. García-Poza, S.; Leandro, A.; Cotas, C.; Cotas, J.; Marques, J.C.; Pereira, L.; Gonçalves, A.M.M. The Evolution Road of Seaweed Aquaculture: Cultivation Technologies and the Industry 4.0. Int. J. Environ. Res. Public Health 2020, 17, 6528. [CrossRef]

5. Bonnans, C.; Chou, J.; Werb, Z. Remodelling the extracellular matrix in development and disease. Nat. Rev. Mol. Cell. Bio. 2014, 15, 786-801. [CrossRef]

6. Takada, Y.; Ye, X.J.; Simon, S. The integrins. Genome Biol. 2007, 8, 215. [CrossRef]

7. Harburger, D.S.; Calderwood, D.A. Integrin signalling at a glance. J. Cell Sci. 2009, 122, 159-163. [CrossRef] [PubMed]

8. Drew, K. Life-history of Porphyra. Nature 1954, 173, 1243-1244. [CrossRef]

9. Kurogi, M. Study of the life-history of Porphyra. I. The germination and development of carpospores. Bull. Tohoku Reg. Fish. Res. Lab. 1953, 2, 67-103.

10. Mukai, L.S.; Craigie, J.S.; Brown, R.G. Chemical composition and structure of the cell walls of the conchocelis and thallus phases of Porphyra tenera (Rhodophyceae). J. Phycol. 1981, 17, 192-197. [CrossRef]

11. Hemmingson, J.; Nelson, W. Cell wall polysaccharides are informative in Porphyra species taxonomy. J. Appl. Phycol. 2002, 14, 357-364. [CrossRef]

12. Cole, K.; Carol, C.M.; Reid, P.E.; Sheath, R.G. Comparative studies on the cell walls of sexual and asexual Bangia atropurpurea (Rhodophyta). I. Histochemistry of polysaccharides. J. Phycol. 1985, 21, 585-592. [CrossRef]

13. Cole, K.; Park, C.M.; Reid, P.E. Comparative studies on the cell walls of sexual and asexual Bangia atropurpurea (Rhodophyta). II. Electrophoretic patterns of polysaccharides. J. Phycol. 1986, 22, 406-409. [CrossRef]

14. Nakamura, Y.; Sasaki, N.; Kobayashi, M.; Ojima, N.; Yasuike, M.; Shigenobu, Y.; Satomi, M.; Fukuma, Y.; Shiwaku, K.; Tsujimoto, A.; et al. The first symbiont-free genome sequence of marine red alga, susabi-nori (Pyropia yezoensis). PLoS ONE 2013, 8, e57122. [CrossRef]

15. Brawley, S.H.; Blouin, N.A.; Ficko-Blean, E.; Wheeler, G.L.; Lohr, M.; Goodson, H.V.; Jenkins, J.W.; Blaby-Haas, C.E.; Helliwell, K.E.; Chan, C.X.; et al. Insights into the red algae and eukaryotic evolution from the genome of Porphyra umbilicalis (Bangiophyceae, Rhodophyta). Proc. Natl. Acad. Sci. USA 2017, 114, 6361-6370. [CrossRef]

16. Cao, M.; Xu, K.P.; Yu, X.Z.; Bi, G.Q.; Liu, Y.; Kong, F.N.; Sun, P.P.; Tang, X.H.; Du, G.Y.; Ge, Y.; et al. A chromosome-level genome assembly of Pyropia haitanensis (Bangiales, Rhodophyta). Mol. Ecol. Resour. 2020, 20, 216-227. [CrossRef] [PubMed]

17. Feinstein, Y.; Borrell, V.; Garcia, C.; Burstyn-Cohen, T.; Tzarfaty, V.; Frumkin, A.; Nose, A.; Okamoto, H.; Higashijima, S.; Soriano, E.; et al. F-spondin and mindin: Two structurally and functionally related genes expressed in the hippocampus that promote outgrowth of embryonic hippocampal neurons. Development 1999, 126, 3637-3648. [CrossRef]

18. Higashijima, S.; Nose, A.; Eguchi, G.; Hotta, Y.; Okamoto, H. Mindin/F-spondin family: Novel ECM proteins expressed in the zebrafish embryonic axis. Dev. Biol. 1997, 192, 211-227. [CrossRef] [PubMed]

19. Umemiya, T.; Takeichi, M.; Nose, A. M-spondin, a novel ECM protein highly homologous to vertebrate F-spondin, is localized at the muscle attachment sites in the Drosophila embryo. Dev. Biol. 1997, 186, 165-176. [CrossRef] [PubMed]

20. Tan, K.; Lawler, J. The structure of the $\mathrm{Ca}^{2+}$-binding, glycosylated F-spondin domain of F-spondin-A C2-domain variant in an extracellular matrix protein. BMC Struct. Biol. 2011, 11, 22. [CrossRef]

21. Klar, A.; Baldassare, M.; Jessell, T.M. F-spondin-A gene expressed at high-levels in the floor plate encodes a secreted protein that promotes neural cell-adhesion and neurite extension. Cell 1992, 69, 95-110. [CrossRef]

22. Altaba, A.R.I.; Cox, C.; Jessell, T.M.; Klar, A. Ectopic neural expression of a floor plate marker in frog embryos injected with the midline transcription factor Pintallavis. Proc. Natl. Acad. Sci. USA 1993, 90, 8268-8272. [CrossRef]

23. Tzarfati-Majar, V.; Burstyn-Cohen, T.; Klar, A. F-spondin is a contact-repellent molecule for embryonic motor neurons. Proc. Natl. Acad. Sci. USA 2001, 98, 4722-4727. [CrossRef] [PubMed]

24. Seifert, G.J. Fascinating Fasciclins: A surprisingly widespread family of proteins that mediate interactions between the cell exterior and the cell surface. Int. J. Mol. Sci. 2018, 19, 1628. [CrossRef]

25. Bastiani, M.J.; Harrelson, A.L.; Snow, P.M.; Goodman, C.S. Expression of fasciclin I and II glycoproteins on subsets of axon pathways during neuronal development in the grasshopper. Cell 1987, 48, 745-755. [CrossRef]

26. Zhong, Y.; Shanley, J. Altered nerve terminal arborization and synaptic transmission in Drosophila mutants of cell adhesion molecule fasciclin I. J. Neurosci. 1995, 15, 6679-6687. [CrossRef]

27. Kim, J.E.; Jeong, H.W.; Nam, J.O.; Lee, B.H.; Choi, J.Y.; Park, R.W.; Park, J.Y.; Kim, I.S. Identification of motifs in the fasciclin domains of the transforming growth factor- $\beta$-induced matrix protein $\beta$ ig-h3 that interact with the $\alpha \mathrm{v} \beta 5$ integrin. J. Biol. Chem. 2002, 277, 46159-46165. [CrossRef]

28. Seifert, G.J.; Roberts, K. The biology of arabinogalactan proteins. Annu. Rev. Plant Biol. 2007, 58, 137-161. [CrossRef]

29. Li, J.; Yu, M.A.; Geng, L.L.; Zhao, J. The fasciclin-like arabinogalactan protein gene, FLA3, is involved in microspore development of Arabidopsis. Plant J. 2010, 64, 482-497. [CrossRef] 
30. Johnson, K.L.; Kibble, N.A.J.; Bacic, A.; Schultz, C.J. A Fasciclin-Like Arabinogalactan-Protein (FLA) Mutant of Arabidopsis thaliana, fla1, Shows Defects in Shoot Regeneration. PLoS ONE 2011, 6, e25154. [CrossRef]

31. Costa, M.; Pereira, A.M.; Pinto, S.C.; Silva, J.; Pereira, L.G.; Coimbra, S. In silico and expression analyses of fasciclin-like arabinogalactan proteins reveal functional conservation during embryo and seed development. Plant Reprod. 2019, 32, 353-370. [CrossRef] [PubMed]

32. Shi, H.; Kim, Y.; Guo, Y. The Arabidopsis SOS5 locus encodes a putative cell surface adhesion protein and is required for normal cell expansion. Plant Cell 2003, 15, 19-32. [CrossRef]

33. Basu, D.; Tian, L.; Debrosse, T.; Poirier, E.; Emch, K.; Herock, H.; Travers, A.; Showalter, M.A. Glycosylation of a fasciclin-like arabinogalactan-protein (SOS5) mediates root growth and seed mucilage adherence via a cell wall receptor-like kinase (FEI1/FEI2) pathway in Arabidopsis. PLoS ONE 2016, 11, e0145092. [CrossRef]

34. Ashagre, A.H.; Zaltzman, D.; Idan-Molakandov, A.; Romano, H.; Tzfadia, O.; Harpaz-Saad, S. FASCICLIN-LIKE 18 is a new player regulating root elongation in Arabidopsis thaliana. Front. Plant Sci. 2021, 12, 645286. [CrossRef]

35. Butterfield, N.J. Bangiomorpha pubescens n. gen., n. sp.: Implications for the evolution of sex, multicellularity, and the Mesoproterozoic/Neoproterozoic radiation of eukaryotes. Paleobiology 2000, 26, 386-404. [CrossRef]

36. Gibson, T.M.; Shih, P.M.; Cumming, V.M.; Fischer, W.W.; Crockford, P.W.; Hodgskiss, M.S.W.; Worndle, S.; Creaser, R.A.; Rainbird, R.H.; Skulski, T.M.; et al. Precise age of Bangiomorpha pubescens dates the origin of eukaryotic photosynthesis. Geology 2018, 46, 135-138. [CrossRef]

37. Kuwano, K.; Aruga, Y.; Saga, N. Cryopreservation of clonal gametophytic thalli of Porphyra (Rhodophyta). Plant Sci. 1996, 116, 117-124. [CrossRef]

38. Provasoli, L. Media and prospects for the cultivation of marine algae. In Culture and Collections of Algae, Proceedings of US-Japan Conference, Hakone, September 1966; Watanabe, A., Hattori, A., Eds.; Japanese Society of Plant Physiologists: Tokyo, Japan, 1968; pp. $63-75$.

39. Uji, T.; Matsuda, R.; Takechi, K.; Takano, H.; Mizuta, H.; Takio, S. Ethylene regulation of sexual reproduction in the marine red alga Pyropia yezoensis (Rhodophyta). J. Appl. Phycol. 2016, 28, 3501-3509. [CrossRef]

40. Uji, T.; Mizuta, H. Treatment with heat shock protein 90 (Hsp90) inhibitors induces asexual life cycle in the marine red alga Neopyropia yezoensis (Rhodophyta). Aquac. Res. 2021, 52, 6814-6817. [CrossRef]

41. Uji, T.; Gondaira, Y.; Fukuda, S.; Mizuta, H.; Saga, N. Characterization and expression profiles of small heat shock proteins in the marine red alga Pyropia yezoensis. Cell Stress Chaperon. 2019, 24, 223-233. [CrossRef] [PubMed]

42. Rao, X.; Huang, X.; Zhou, Z.; Lin, X. An improvement of the $2^{\wedge}(-$ delta delta CT) method for quantitative real-time polymerase chain reaction data analysis. Biostat. Bioinform. Biomath. 2013, 3, 71-85.

43. Uji, T.; Takahashi, M.; Saga, N.; Mikami, K. Visualization of nuclear localization of transcription factors with cyan and green fluorescent proteins in the red alga Porphyra yezoensis. Mar. Biotechnol. 2010, 12, 150-159. [CrossRef]

44. Conesa, A.; Götz, S.; García-Gómez, J.M.; Terol, J.; Talón, M.; Robles, M. Blast2GO: A universal tool for annotation, visualization and analysis in functional genomics research. Bioinformatics 2005, 21, 3674-3676. [CrossRef] [PubMed]

45. Duvaud, S.; Gabella, C.; Lisacek, F.; Stockinger, H.; Ioannidis, V.; Durinx, C. Expasy, the Swiss Bioinformatics Resource Portal, as designed by its users. Nucleic Acids Res. 2021, 49, 216-227. [CrossRef] [PubMed]

46. Pei, J.; Kim, B.H.; Grishin, N.V. PROMALS3D: A tool for multiple protein sequence and structure alignments. Nucleic Acids Res. 2008, 36, 2295-2300. [CrossRef] [PubMed]

47. Nakai, K.; Horton, P. PSORT: A program for detecting sorting signals in proteins and predicting their subcellular localization Trends Biochem Sci. 1999, 24, 34-36. [CrossRef]

48. Gupta, R.; Brunak, S. Prediction of glycosylation across the human proteome and the correlation to protein function. Pac. Symp. Biocomput. 2002, 7, 310-322.

49. Li, Y.L.; Cao, C.Z.; Jia, W.; Yu, L.L.; Mo, M.; Wang, Q.; Huang, Y.P.; Lim, J.M.; Ishihara, M.; Wells, L.; et al. Structure of the F-spondin domain of mindin, an integrin ligand and pattern recognition molecule. EMBO J. 2009, 28, 286-297. [CrossRef]

50. Johnson, K.L.; Jones, B.J.; Bacic, A.; Schultz, C.J. The fasciclin-like arabinogalactan proteins of Arabidopsis. A multigene family of putative cell adhesion molecules. Plant Physiol. 2003, 133, 1911-1925. [CrossRef]

51. Kim, J.E.; Kim, S.J.; Lee, B.H.; Park, R.W.; Kim, K.S.; Kim, I.S. Identification of motifs for cell adhesion within the repeated domains of transforming growth factor-beta-induced gene, beta ig-h3. J. Biol. Chem. 2000, 275, 30907-30915. [CrossRef]

52. Ma, Y.L.; Yan, C.C.; Li, H.M.; Wu, W.T.; Liu, Y.X.; Wang, Y.Q.; Chen, Q.; Ma, H.L. Bioinformatics prediction and evolution analysis of arabinogalactan proteins in the plant kingdom. Front. Plant Sci. 2017, 8, 66. [CrossRef]

53. Ma, H.L.; Zhao, J. Genome-wide identification, classification and expression analysis of the arabinogalactan protein gene family in rice (Oryza sativa L.). J. Exp. Bot. 2010, 61, 2647-2668. [CrossRef]

54. Uji, T.; Endo, H.; Mizuta, H. Sexual reproduction via a 1-aminocyclopropane-1-carboxylic acid-dependent pathway through redox modulation in the marine red alga Pyropia yezoensis (Rhodophyta). Front. Plant Sci. 2020, 11, 60. [CrossRef]

55. Endo, H.; Mizuta, H.; Uji, T. $\alpha$-aminoisobutyric acid mimics the effect of 1-aminocyclopropane-1-carboxylic acid to promote sexual reproduction in the marine red alga Pyropia yezoensis (Rhodophyta). J. Appl. Phycol. 2021, 33, 1081-1087. [CrossRef]

56. Seifert, G.J.; Blaukopf, C. Irritable Walls: The Plant Extracellular Matrix and Signaling. Plant Physiol. 2010, 153, 467-478. [CrossRef] [PubMed] 
57. Stahelin, R.V.; Cho, W. Roles of calcium ions in the membrane binding of C2 domains. Biochem. J. 2001, 359, 679-685. [CrossRef] [PubMed]

58. Feinstein, Y.; Klar, A. The neuronal class 2 TSR proteins F-spondin and Mindin: A small family with divergent biological activities. Int. J. Biochem. Cell Biol. 2004, 36, 975-980. [CrossRef] [PubMed]

59. Huber, O.; Sumper, M. Algal-CAMs: Isoforms of a cell adhesion molecule in embryos of the alga Volvox with homology to Drosophila fasciclin I. EMBO J. 1994, 13, 4212-4222. [CrossRef] [PubMed]

60. Drew, K. Studies in the Bangioideae III. The Life-history of Porphyra umbilicalis (L.) Kütz. var. lociniata (Lightf.) J. Ag.: A. The Conchocelis-Phase in culture. Ann. Bot. 1954, 18, 183-184. [CrossRef]

61. Tsai, A.Y.; Kunieda, T.; Rogalski, J.; Foster, L.J.; Ellis, B.E.; Haughn, G.W. Identification and characterization of Arabidopsis seed coat mucilage proteins. Plant Physiol. 2017, 173, 1059-1074. [CrossRef]

62. Ouriques, L.C.; Schmidt, E.C.; Bouzon, Z.L. The mechanism of adhesion and germination in the carpospores of Porphyra spiralis var. amplifolia (Rhodophyta, Bangiales). Micron 2012, 43, 269-277. [CrossRef]

63. Gu, J.G.; Isaji, T.; Xu, Q.S.; Kariya, Y.; Gu, W.; Fukuda, T.; Du, Y.G. Potential roles of N-glycosylation in cell adhesion. Glycoconj. J. 2012, 29, 599-607. [CrossRef] [PubMed]

64. Janik, M.E.; Litynska, A.; Vereecken, P. Cell migration-The role of integrin glycosylation. Biochim. Biophys. Acta 2010, 1800, 545-555. [CrossRef] [PubMed]

65. Yanagisawa, R.; Sekine, N.; Mizuta, H.; Uji, T. Transcriptomic analysis under ethylene precursor treatment uncovers the regulation of gene expression linked to sexual reproduction in the dioecious red alga Pyropia pseudolinearis. J. Appl. Phycol. 2019, 31, 3317-3329. [CrossRef] 